\title{
Does shaming have a place in public health?
}

Cite as: CMAJ 2021 January 11;193:E59-60. doi: 10.1503/cmaj.1095910

Posted on cmajnews.com on December 11, 2020

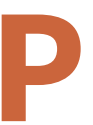

eople have been quick to call out others for public health failures during the pandemic, especially as those measures have become more politically divisive. But does it do any good?

Studies link blame and shame to worse public health outcomes when it comes to HIV, obesity and fetal alcohol syndrome. And experts warned early in the pandemic that shame and guilt about public health flubs may lead to less transparency about severe acute respiratory syndrome coronavirus 2 (SARS-CoV-2) infection status and potential contacts.

However, some physicians argue they have a responsibility to call out people who blatantly defy public health orders and put others' lives at risk. And some forms of peer pressure may be helpful in achieving public health goals.

Dr. Naheed Dosani is a Toronto-based palliative care physician who cares for people without stable housing. He says it was frustrating to see local officials take several days to shut down Adamson Barbecue, a restaurant that refused to comply with pandemic restrictions, when authorities have been quick to police vulnerable communities' adherence to public health directives. Dosani says the level of public support for the restaurant felt like a "slap in the face" to front-line workers.

"I just supported a woman by phone who was in tears because she so badly wants to see her husband in hospital, who has \#COVID19," Dosani posted on Twitter. "She can't see her sick husband who really needs her, but a restaurant owner in Etobicoke can defy orders \& offer indoor dining?"

Dosani told CMAJ it's important for physicians to use their position and privilege to challenge the "counter-



Some forms of social pressure may be helpful but blame may backfire.

cultural movement against science and evidence" that has emerged during the pandemic. Since tweeting about the restaurant, he has received insults and death threats from people opposed to public health measures.

"It's hard to think about the kind of world we live in right now, where a physician is standing up for evidencebased and scientifically supported interventions in this pandemic and is getting death threats," Dosani says. "It's more crucial than ever that health care workers, and particularly physicians, stand up and speak out against conspiracy theorists, anti-maskers, and anybody who is creating a movement that moves us away from the pandemic protocol."

However, he notes there is a difference between calling out people who knowingly defy the rules and shaming those who make mistakes.
Take the case of Dr. Jean Robert Ngola, who was publicly shamed and blamed for a cluster of COVID-19 cases in New Brunswick earlier this year, even though it's still unclear whether he was patient zero in the outbreak.

In early May, Ngola left his shift at Campbellton Region Hospital, crossed the New Brunswick-Quebec border to pick up his four-year-old daughter. He did not self-isolate upon return, believing he was following the rules for essential workers.

When Ngola later tested positive for SARS-CoV-2, he was "singled out by the premier of New Brunswick, publicly shamed and outed on social media," according to his lawyer. Within hours, Ngola's employer suspended him without pay, and within a week, the Royal Canadian Mounted Police began investigating him for criminal wrongdoing. 
More than 1500 physicians across Canada have since signed a letter of solidarity with Ngola, stating that he was judged "prior to due diligence being conducted."

According to Dr. Nav Persaud, a Canada Research Chair in Health Justice, "I don't think there was ever any reason to think this doctor was acting recklessly with the intent of harming anyone. It shows how clumsy these attempts to blame individuals for contributing to the pandemic can be."

Persaud also questions why so many police resources were dedicated to the case. "As a racialized physician, when there's even a question about your conduct, the police get called on you," he says. "We need a public health response to the pandemic, not a criminal justice response."

Persaud argues that politicians benefit from shifting the blame for outbreaks onto individuals because it distracts attention from gaps in the broader pandemic response. For example, instead of shaming young people for gathering in parks which likely led to few cases of COVID-19officials could be reducing crowding on busy transit routes frequented by essential workers, where the virus may be more likely to spread.

Research shows that people's attitudes toward public health measures like vaccination are influenced by their peers and role models. And harnessing that influence in a positive way could boost compliance in public health measures, says Ian Culbert, executive director of the Canadian Public Health Association. For example, a group of university students could convince their friends not to attend a party.
But the power dynamic is different when politicians or health officials single out individuals, and shaming often backfires in a public health context. "It's actually self-defeating because it makes the person feel inadequate or like they've failed at something, and therefore takes away their incentive or sometimes even their ability to make a change for the better," Culbert says.

Anti-smoking campaigns have used shaming messages effectively to motivate some smokers to quit. However, public health experts warn this approach may lead some smokers to attempt to quit in isolation and therefore may contribute to increased stress and symptom burden.

Pandemic rule-breakers who put other people at risk may "deserve shame," but it doesn't serve the bigger goal of bringing them onside, says Steve Joordens, a psychology professor at the University of Toronto. "What we want to do is convince them to want to do the right thing, so we want to strengthen any tendency they might have to do what we're all doing and be like us, rather than draw a separation between 'us' and 'them.'"

Joordens says people opposed to lockdown measures are typically responding from emotions like fear, rather than rational thought, so public health messages that emphasize the facts over feelings may miss their mark. One recent study found that people were more likely to follow physical distancing guidelines and wear face masks after watching videos of vulnerable people talking about how COVID-19 has affected their daily lives, compared to people who received information only about the benefits of public health measures.

Samantha Yammine, a Toronto-based neuroscientist and popular science communicator known as Science Sam, says positive modelling and sharing risk reduction approaches are more helpful than shaming and blaming. Sharing ideas of ways to have fun while following public health guidelines also builds community and a sense of hope, making it more likely people will follow the rules in the long-term, she says.

According to Dr. Noni MacDonald, an infectious disease specialist and professor of pediatrics at Dalhousie University, shame may achieve short-term compliance, but positive messages will go further to sustain community support for public health measures. She points to the German government's recent video series celebrating couch potatoes as heroes of the pandemic. Such messages unite, rather than divide, MacDonald says. "We are all in this together. Each of us is only safe if the others are safe."

\section{Diana Duong, CMAJ}

Disclaimer: Nav Persaud is an associate editor for CMAJ and was not involved in the editorial decision-making for this article.

Content licence: This is an Open Access article distributed in accordance with the terms of the Creative Commons Attribution (CC BY-NC-ND 4.0) licence, which permits use, distribution and reproduction in any medium, provided that the original publication is properly cited, the use is noncommercial (i.e., research or educational use), and no modifications or adaptations are made. See: https://creativecommons.org/ licenses/by-nc-nd/4.0/ 